medRxiv preprint doi: https://doi.org/10.1101/2020.12.10.20245662; this version posted December $14,2020$. The copyright holder for this preprint (which was not certified by peer review) is the author/funder, who has granted medRxiv a license to display the preprint in perpetuity.

It is made available under a CC-BY-NC-ND 4.0 International license .

\title{
Aerosol generation in children undergoing high flow nasal cannula therapy
}

Elliott T. Gall, Ph.D. ${ }^{a}$, Aurélie Laguerre, M.S. ${ }^{a}$, Michelle Noelck, MD ${ }^{\mathrm{b}}$, Annalise Van Meurs, $4 \quad \mathrm{MD}^{\mathrm{b}}$, Jared A Austin, MD, ${ }^{\mathrm{b}}$ Byron A. Foster, MD, MPH ${ }^{\mathrm{b}, \mathrm{c}}$

Affiliations: ${ }^{a}$ Department of Mechanical and Materials Engineering, Portland State University, ${ }^{b}$ Department of Pediatrics, School of Medicine, Oregon Health \& Science University, ${ }^{\mathrm{c} O H S U}$ -

8 PSU School of Public Health

Address correspondence to: Byron A. Foster, MD, MPH, 3181 SW Sam Jackson Park Rd, MC CDRC-P, Portland, OR 97239

Funding source: The Doernbecher Philanthropy Board provided funding for the study.

Financial disclosure: The authors have indicated they have no financial relationships relevant to this article to disclose.

Conflict of interest statement: The authors have indicated they have no potential conflicts of interest to disclose.

Data sharing statement: Deidentified individual participant data will not be made available.

Measurements of constituents in air made in participant rooms will be made available upon reasonable request.

\section{Contributor statements:}

Dr. Gall contributed to the study conception, design, data analysis and drafting the manuscript. Ms. Laguerre contributed to the study design, was the primary data collector, contributed to the analysis and writing the manuscript.

Dr. Noelck contributed to the study design, execution of the study and revised the manuscript.

Dr. Van Meurs contributed to the recruitment, data collection and revised the manuscript.

Dr. Austin contributed to the study design and revised the manuscript.

Dr. Foster contributed to the study conception, design, recruitment, data collection and drafting the manuscript.

Acknowledgements: We thank the families who volunteered to participate in the study. Paula Bennett, MSN, MHA, RN, Brenda Rickert, MSN, RN, Emily Palmquist, MSN, RN, Rachel Coleman, BS, RRT-NPS, many respiratory therapy staff and the Hospital Chief Engineer, 


\section{Abstract}

42

\section{Objective}

44 High flow nasal cannula therapy (HFNC) may increase aerosol generation, putting health care 45 workers at increased risk of infection, including from SARS-CoV-2. This study examined

46 whether use of HFNC increases near-field aerosols and if there is a relationship between flow

47 rate and near-field aerosol concentrations.

\section{Patients and Methods}

50 Subjects between 30 days and 2 years of age were enrolled. Each child received HFNC therapy

51 at different flow rates over time. Three sampling stations with particle counters were deployed to

52 measure aerosol generation and dispersion in the room: station one within $0.5 \mathrm{~m}$ of the subject,

53 station two at $2 \mathrm{~m}$, and station three on the other side of the room. We also measured carbon

54 dioxide $\left(\mathrm{CO}_{2}\right)$ and relative humidity. Station three (far-field) measurements were used to adjust

55 the station one (near-field) measurements for room conditions.

Results

58 We enrolled ten children ranging from 6-24 months (median 9 months), two with respiratory 59 illness. Elevated $\mathrm{CO}_{2}$ indicated the near-field measurements were in the breathing plane of the 60 subjects. Near-field breathing plane concentrations of aerosols with diameter $0.3-10 \mu \mathrm{m}$ are

61 elevated by the presence of the patient with no HFNC flow, relative to the room far-field, by 0.45

$62 \# / \mathrm{cm}^{3}$. While we observed variability between subjects in their emission and dispersion of

63 particles, we did not find an association between HFNC and near-field elevations of particle

64 counts.

65

66 Conclusion

67 Near-patient levels of particles with diameter in the 0.3-10 $\mu \mathrm{m}$ range was not affected by the use

68 of HFNC in healthy patients. Further study on older children and children with increased mucus 69 production may be warranted. 
medRxiv preprint doi: https://doi.org/10.1101/2020.12.10.20245662; this version posted December $14,2020$. The copyright holder for this preprint (which was not certified by peer review) is the author/funder, who has granted medRxiv a license to display the preprint in perpetuity.

It is made available under a CC-BY-NC-ND 4.0 International license .

\section{Introduction}

High flow nasal cannula therapy (HFNC) provides respiratory support for hospitalized children across a range of ages and diagnoses including asthma, pneumonia and bronchiolitis. World Health Organization (WHO) guidance suggests that HFNC does not cause wide-spread dispersion of droplets from patients. ${ }^{1}$ However, empirical data in clinical settings is lacking on whether HFNC contributes to aerosol generation. While children typically have more mild and even asymptomatic infections with SARS-CoV-2, respiratory disease and co-infection with other viruses have been reported. ${ }^{2}$ During the COVID-19 pandemic, HFNC has been treated as an aerosol generating procedure (AGP) in the United States given concern around particle generation, typically characterized in the health care field as transmission by droplet $(\geq 5 \mu \mathrm{m})$ and droplet nuclei $(<5 \mu \mathrm{m}){ }^{3}{ }^{3}$ This requires use of N-95 masks, gowns, and other personal protective equipment when patients are receiving HFNC. Determining the risk of aerosol generation from HFNC has important implications for resource management and infection control measures. Several studies have investigated transport of large droplets from patients undergoing HFNC. Kotoda et al. ${ }^{4}$ used a mannequin model to examine the effect of high flow nasal cannula at $60 \mathrm{~L} / \mathrm{min}$ and observed large droplets $(>50 \mu \mathrm{m})$ at $30 \mathrm{~cm}$, but not $5 \mathrm{~m}$ from the mannequin's face. A report examining adults coughing with and without the application of high flow nasal cannula (60 L/min) showed no significant difference in the distance of "visible" food-dye containing droplets; ${ }^{5}$ the length scale of droplets is not noted, though visible particles are often classified as those $>100 \mathrm{um}$. These studies indicate large droplets are not effectively transported over long distances due to the forced air exiting the patient's nasal and oral cavity

Studies have employed smoke as a tracer to evaluate impacts of HFNC on room air flows and as proxies of exhaled air exposure. Hui et al. ${ }^{6}$ used intrapulmonary smoke in a mannequin 
medRxiv preprint doi: https://doi.org/10.1101/2020.12.10.20245662; this version posted December $14,2020$. The copyright holder for this preprint (which was not certified by peer review) is the author/funder, who has granted medRxiv a license to display the preprint in perpetuity.

It is made available under a CC-BY-NC-ND 4.0 International license .

96 model to evaluate enhancement of exhaled air, measured by the extent of light-scattering as a

97 function of distance from the patient. They showed an increase in "exhaled air dispersion" from

$9865 \mathrm{~mm}$ with HFNC flow of $10 \mathrm{~L} / \mathrm{min}$ to $172 \mathrm{~mm}$ with HFNC flow of $60 \mathrm{~L} / \mathrm{min}$. Using smoke

99 particles as tracers and an adult human head with a lung model attached, Elshof et al. ${ }^{7}$ examined

100 the dispersion of $100 \mu \mathrm{m}$ droplets using HFNC with a lung simulator. They described an

101 estimated dispersion range of $100 \mu \mathrm{m}$ droplets of between 18.8 and $33.4 \mathrm{~cm}$ from the individual

102 using flow rates between 30-60 L/min. They also noted that HFNC increased the distance of

103 exhaled smoke to nearly one meter under several conditions whereas a non-rebreather or Venturi

104 mask did not influence the distance beyond normal breathing. ${ }^{7}$

105 This study sought to examine whether HFNC therapy use in children generates elevated

106 particle levels in the near-field $(0.5 \mathrm{~m})$ of the patient's breathing plane. We measured

107 concentrations of particles and carbon dioxide (as an exhaled breath tracer) in rooms in a clinical

108 care facility with varying HFNC flow rates for each patient. Our study addresses several

109 knowledge gaps concerning HFNC and particle generation and dispersion as it: i) addresses an

110 unstudied population, children, ii) was conducted in a clinical care facility with human subjects,

111 and iii) directly measured aerosols with diameter $0.3-10 \mu \mathrm{m}$ and carbon dioxide in the near-

112 field breathing plane and room far-field. The goal was to generate data to inform the safe use of

113 this therapy and inform resource management and infection control measures.

\section{Methods}

115 This study was a prospective study looking at aerosol generation and dispersion from

116 pediatric patients on high-flow nasal cannula (HFNC) in a typical pediatric hospital room.

117 Subject eligibility and recruitment: 
medRxiv preprint doi: https://doi.org/10.1101/2020.12.10.20245662; this version posted December 14, 2020. The copyright holder for this preprint (which was not certified by peer review) is the author/funder, who has granted medRxiv a license to display the preprint in perpetuity.

It is made available under a CC-BY-NC-ND 4.0 International license .

119 criteria were gestation-corrected age 4 weeks to 24 months, no chronic cardiopulmonary

120 conditions, and currently healthy with no Sars-Cov2 exposure or symptoms.

121 Ethics:

This study was approved as human subjects research through the OHSU IRB, and all

123 parents provided written consent to participate.

Experimental procedure:

Hospital rooms were chosen from available pediatric acute care rooms (patient room,

126 hereafter, and shown in Figure 1) and one procedure room at a tertiary care hospital in the Pacific

127 Northwest. Patient and procedure rooms had floor area $\sim 24 \mathrm{~m}^{2}$ and $\sim 17 \mathrm{~m}^{2}$, respectively. $\mathrm{CO}_{2}$

128 tracer decay tests conducted in patient and procedure rooms resulted in an air-change rate of 8.4

129 and $11.0 \mathrm{~h}^{-1}$, respectively (Figure S1 of Supporting Information). Air entering the rooms is

130 treated with MERV10 and MERV15 filtration.

131 Figure 1. Panel A) Layout of patient room and sampling locations, and Panel B) Timeline of 132 experiments for each patient
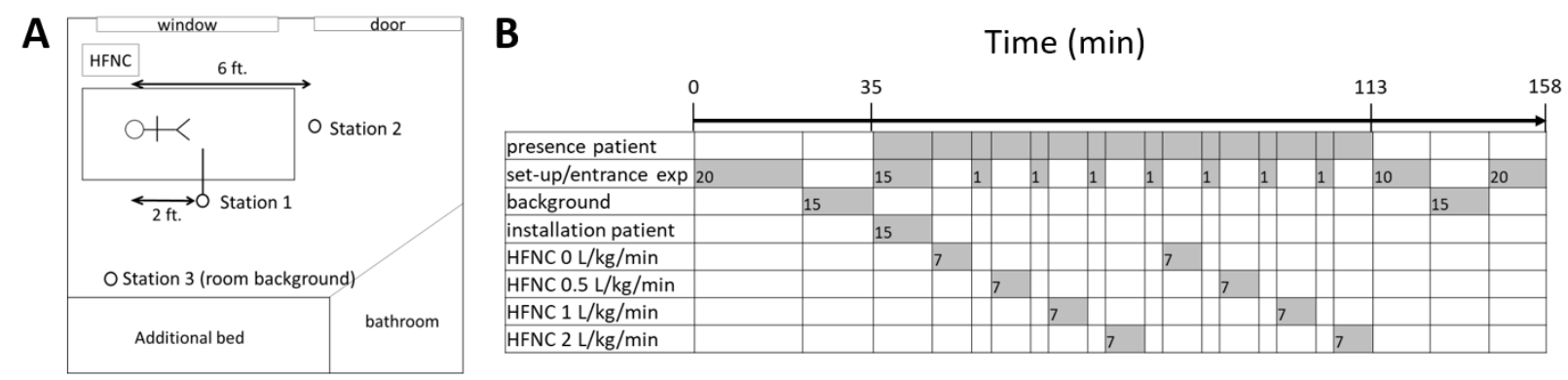

Subjects were placed on a hospital bed with a parent in the room, with the parent wearing

135 a cloth or surgical mask at all times. A high-flow nasal cannula system (Fisher and Paykel's

136 Optiflow Junior, circuit RT 330) with an appropriately sized nasal cannula for each subject's size

137 and weight was set-up by a qualified respiratory therapist. 
medRxiv preprint doi: https://doi.org/10.1101/2020.12.10.20245662; this version posted December $14,2020$. The copyright holder for this preprint (which was not certified by peer review) is the author/funder, who has granted medRxiv a license to display the preprint in perpetuity.

It is made available under a CC-BY-NC-ND 4.0 International license .

Ambient air in the hospital room was sampled with the door closed and no patient present

139 (background condition) for 15 minutes. The child was then connected to the HFNC, flow was

140 then increased from 0 to $0.5 \mathrm{~L} / \mathrm{kg} / \mathrm{min}$, to $1 \mathrm{~L} / \mathrm{kg} / \mathrm{min}$ then finally to $2 \mathrm{~L} / \mathrm{kg} / \mathrm{min}$, then back to 0

$141 \mathrm{~L} / \mathrm{kg} / \mathrm{min}$ and repeated the cycle one more time for a total of two measurements per subject at

142 each flow rate. Each cycle lasted about seven minutes. An experimental timeline is shown in

143 Figure 1 . HFNC air was heated to approximately $37^{\circ} \mathrm{C}$ and humidified. No supplementary

144 oxygen was provided. We conducted a positive control following the completion of the protocol

145 twice over the course of the study. In this control, particle and $\mathrm{CO}_{2}$ levels were measured in the

146 breathing plane $\sim 0.5 \mathrm{~m}$ from the nasal/oral cavity of member of the research team during and

147 after volitional coughing .

148 We recruited ten children ranging from 6-23 months (median nine months) and their

149 parents to participate in the study between September and November 2020. The median weight

150 of participants was $9.8 \mathrm{~kg}$ (range $7.3-14.0 \mathrm{~kg}$ ). The flow rates were calculated for each child at

$1510.5 \mathrm{~L} / \mathrm{kg} / \mathrm{min}, 1 \mathrm{~L} / \mathrm{kg} / \mathrm{min}$ and $2 \mathrm{~L} / \mathrm{kg} / \mathrm{min}$ with a max flow rate in this study of $25 \mathrm{~L} / \mathrm{min}$, which

152 two of the participants reached. Note that two patients (P02 and P03) were excluded from

153 subsequent analysis as measurements occurred during periods of extremely elevated outdoor air

154 pollution due to wildfires in the region; background particle concentrations were substantially

155 elevated in the patient rooms. For patients with respiratory illness (P08 and P10), we were not

156 able to vary the HFNC flowrate and could not access the room prior to patient occupancy for

157 background measurement.

158 Particle and carbon dioxide measurement:

159 Three sampling stations were deployed in the room of each study participant prior to their

160 arrival, excepting P08 and P10 who were present prior to sampling. The main sampling location 
medRxiv preprint doi: https://doi.org/10.1101/2020.12.10.20245662; this version posted December $14,2020$. The copyright holder for this preprint (which was not certified by peer review) is the author/funder, who has granted medRxiv a license to display the preprint in perpetuity.

It is made available under a CC-BY-NC-ND 4.0 International license .

161 (station 1, Figure 1) consisted of a common $0.9 \mathrm{~m}$ sampling line with inlet installed in the

162 patient's breathing plane at distance $\sim 0.5 \mathrm{~m}$ from the breathing zone, similar to O'Neil et. al ${ }^{8}$.

163 The tubing was $0.95 \mathrm{~cm}$ outer diameter conductive tubing (Bev-a-line) with the inlet directed

164 towards the patient. The sampling line was connected to a stainless-steel manifold with ports for

165 four instruments. An optical particle sizer (TSI/OPS 3330) and scanning mobility particle sizer

166 (TSI/NanoScan SMPS 3910) counted particles ranging from 0.01 to $10 \mu \mathrm{m}$ at a time resolution

167 of one-minute. A condensation particle counter (TSI, P-Trak 8525) measured particles ranging

1680.02 to $1 \mu \mathrm{m}$ in one second time interval. Isokinetic sampling was not possible due to the

169 variability in airflows in the room and due to the exhalations of the patient. $\mathrm{A} \mathrm{CO}_{2}$ analyzer

170 (LICOR LI-820) measured $\mathrm{CO}_{2}$ levels in one second interval. A temperature and relative

171 humidity sensor (Onset, S-THB-M002) measured in one-minute interval. The patient was not

172 required to maintain a particular position to ensure their exhalations were directed towards the

173 sampling inlet, per IRB requirements.

174

Two additional sampling stations (station 2 and 3, Figure 1) were installed to monitor the

175 room. Each station included a low-cost particle counter (Purple Air, PA-II-SD), measuring

176 particle number concentration in six size bins from $0.3-10 \mu \mathrm{m}$ and recording every 80 seconds,

177 and $\mathrm{CO}_{2}$ sensor (Onset, $\mathrm{MX} 1102$ ) recording every minute. Sampling station 2 was installed $\sim 2$

$178 \mathrm{~m}$ from the patient's breathing zone, roughly in line with the breathing plane established by

179 sampling station 1. Sampling station 3 was placed on the other side of the room away from the

180 patient. In this study, we normalize the data reported by station 1 (near-field) to that of station 3

181 (far-field), which we take as the ambient room particle and $\mathrm{CO}_{2}$ level. Note that we lacked

182 particle number concentrations $<0.3 \mu \mathrm{m}$ in the station 2 and 3 locations; this investigation

183 subsequently focuses on $\mathrm{PM}_{0.3-10 .}$ 
medRxiv preprint doi: https://doi.org/10.1101/2020.12.10.20245662; this version posted December 14, 2020. The copyright holder for this preprint (which was not certified by peer review) is the author/funder, who has granted medRxiv a license to display the preprint in perpetuity.

It is made available under a CC-BY-NC-ND 4.0 International license.

184

185

186

187

188

189

$$
C F(x)=\frac{\overline{P M_{O P S}(x)}}{\overline{P M_{P A}(x)}}
$$

190 where $C F(x)$ is the correction factor for size bin $\mathrm{x}, \overline{P M_{O P S}(x)}$ is the time-averaged OPS value in 191 size bin $\mathrm{x}$, and $\overline{P M_{P A}(x)}$ is the time-averaged PA value in size bin $\mathrm{x}$.

to participants and researchers who were familiarizing and setting up the patient room,

194 respectively. We used a linear regression to correct the values given by the fair-field $\mathrm{CO}_{2}$ sensor

195 (Onset MX1102) to that of the LICOR LI-820 during the 15-minute background period.

Calculations of $\triangle P M$ and $\triangle C O 2$ :

To account for the changing concentration of $\mathrm{PM}_{0.3-10}$ and $\mathrm{CO}_{2}$ in the room due to

$200\left(\# / \mathrm{cm}^{3}\right)$ and $\Delta \mathrm{CO}_{2}(\mathrm{ppm})$ calculated as shown in equations 2 and 3:

$$
\begin{aligned}
& \Delta P M(t)=P M_{\text {near }}(t)-P M_{\text {far }}(t) \\
& \Delta C O_{2}(t)=C O_{2 \text { near }}(t)-C O_{2 \text { far }}(t)
\end{aligned}
$$

eq. 2 
medRxiv preprint doi: https://doi.org/10.1101/2020.12.10.20245662; this version posted December 14, 2020. The copyright holder for this preprint (which was not certified by peer review) is the author/funder, who has granted medRxiv a license to display the preprint in perpetuity.

It is made available under a CC-BY-NC-ND 4.0 International license .

201 where $P M_{-} n e a r(t)$ is the time-varying particle concentration at station $1\left(\# / \mathrm{cm}^{3}\right), P M_{-} f a r(t)$ is

202 the corrected (i.e., eq. 1) particle concentration at station 3, $\mathrm{CO}_{-}(2$ near $)(t)$ is $\mathrm{CO}_{2}$

203 concentration at station $1(\mathrm{ppm})$, and $\mathrm{CO}_{2}$ far $(t)$ is the corrected $\mathrm{CO}_{2}$ concentration at station 3

204 (ppm).

205 Results:

206 Measurements of particle concentrations, $\mathrm{CO}_{2}$, temperature and $\mathrm{RH}$ for two example

207 patients are shown in Figure 2. In the top panel, room particle concentrations are reported in the 208 near-field breathing plane (station 1) and far-field (station 3) of the room, with the second panel

209 showing the difference $\left(\Delta \mathrm{PM}_{0.3-10}\right)$. For patient 01 , near-field is generally higher than far-field,

210 and coincided with generally positive, and during the second replicates sharp spikes in, measured

$211 \Delta \mathrm{CO}_{2}$. This implies measurements captured patient exhalations, as the only source of $\mathrm{CO}_{2}$ in the

212 room is the patient. Conversely, in Patient 06 there are lower levels of particles in the near-field

213 vs. far-field, possibly due to a low generation rate, room mixing conditions, and/or non-human

214 sources of particles during this experiment. For positive controls we observe elevated particle 215 and $\mathrm{CO}_{2}$ concentrations following the volitional cough.

216

217

218

219

220

221

222

223 
medRxiv preprint doi: https://doi.org/10.1101/2020.12.10.20245662; this version posted December 14, 2020. The copyright holder for this preprint (which was not certified by peer review) is the author/funder, who has granted medRxiv a license to display the preprint in perpetuity.

It is made available under a CC-BY-NC-ND 4.0 International license .

224 Figure 2. Example particle and $\mathrm{CO}_{2}$ concentrations in the breathing plane of two patients.

225 Shading annotations shows the condition of the experimental protocol.

Patient 01
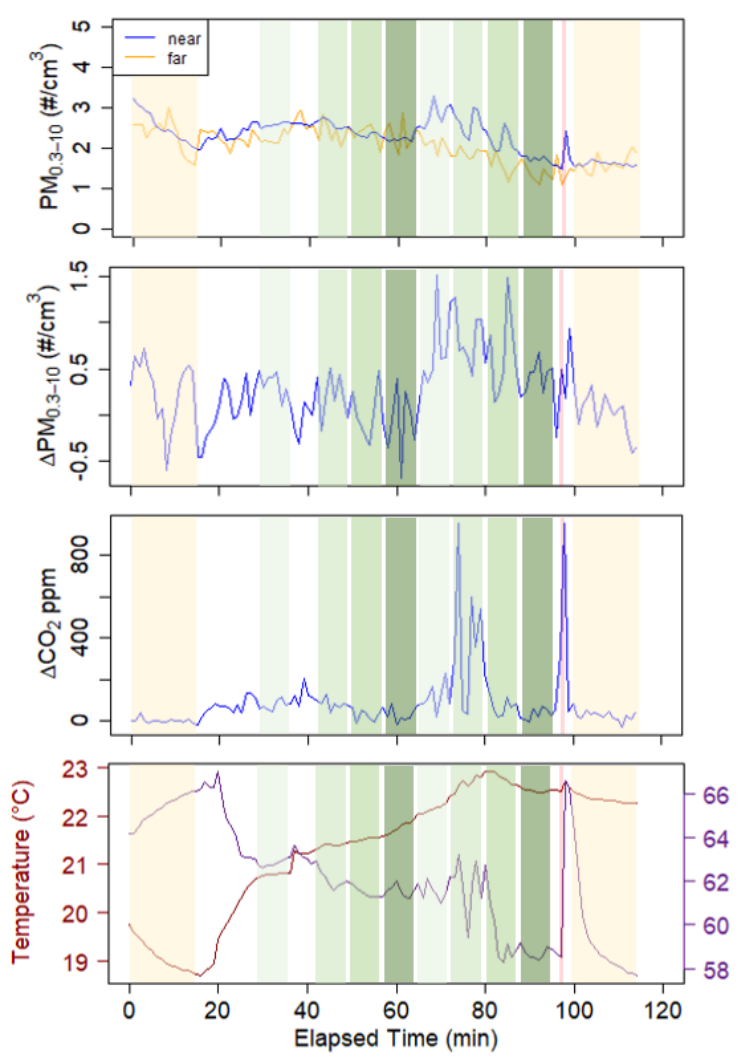

Background = empty room $\mathrm{HFNC} 0 \mathrm{~L} / \mathrm{kg} / \mathrm{min}=$ Baseline
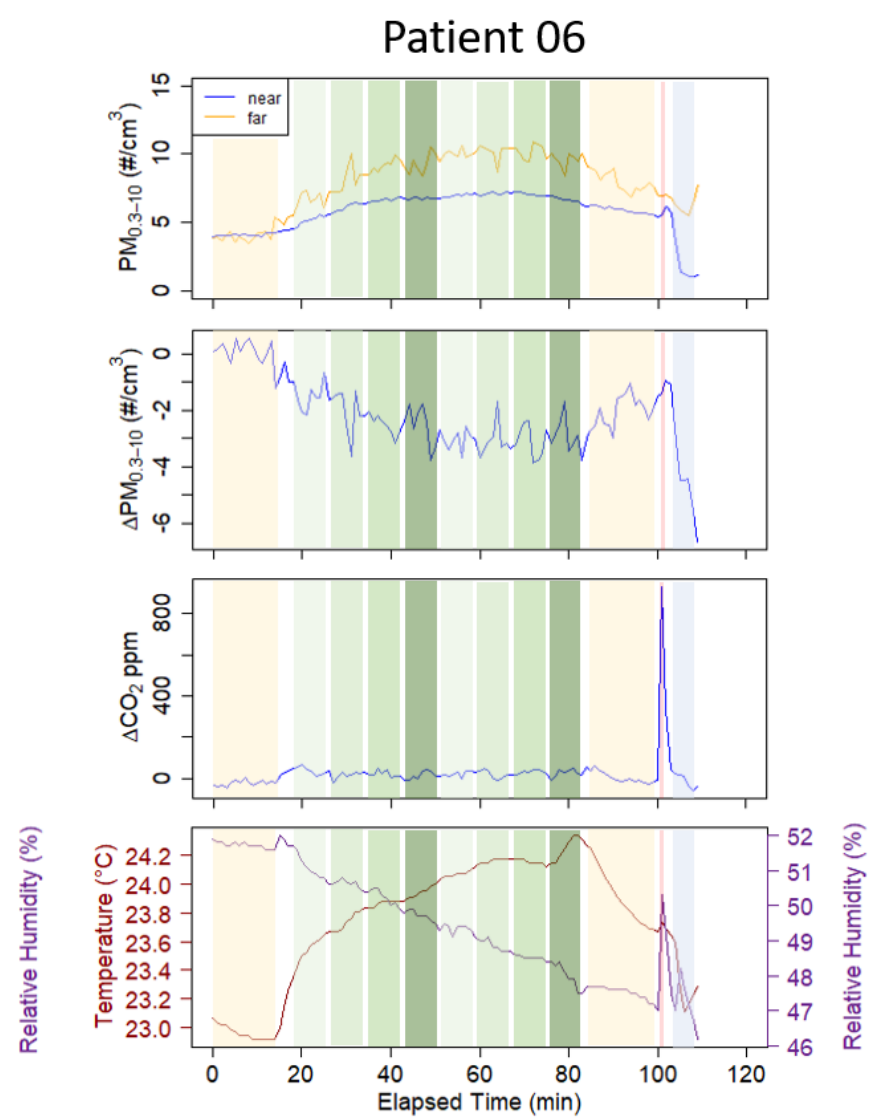

HFNC $0.5 \mathrm{~L} / \mathrm{kg} / \mathrm{min}$ HFNC $2 \mathrm{~L} / \mathrm{kg} / \mathrm{min} \quad$ Zero check

HFNC $1 \mathrm{~L} / \mathrm{kg} / \mathrm{min} \quad$ Positive control

Across the six patients enrolled in the study with acceptable background PM,

distributions of $\triangle \mathrm{PM}$ and $\Delta \mathrm{CO}_{2}$ are shown in Figure 3 across baseline conditions (HFNC at 0

L/kg/min), HFNC with flow, and positive control. Similar plots are shown for size-resolved

flow does not significantly increase median $\Delta \mathrm{PM}_{0.3-10}$ compared to the baseline condition. 
medRxiv preprint doi: https://doi.org/10.1101/2020.12.10.20245662; this version posted December 14, 2020. The copyright holder for this preprint (which was not certified by peer review) is the author/funder, who has granted medRxiv a license to display the preprint in perpetuity.

It is made available under a CC-BY-NC-ND 4.0 International license .

234 Figure 3. Panel A) Distributions of measured $\Delta \mathrm{PM}_{0.3-10}$ and Panel B) $\Delta \mathrm{CO}_{2}$ for six patients

235 involved in this study. Centerline of box plots report median, extent of box is $25^{\text {th }}$ and $75^{\text {th }}$

236 percentiles, and whisker designates upper and lower extent of outliers in the distribution. Note

237 that $\Delta$ indicates reported measurements are the difference between the near-field breathing plane

238 and the coincident ambient room concentration (far-field), as explained in the text.

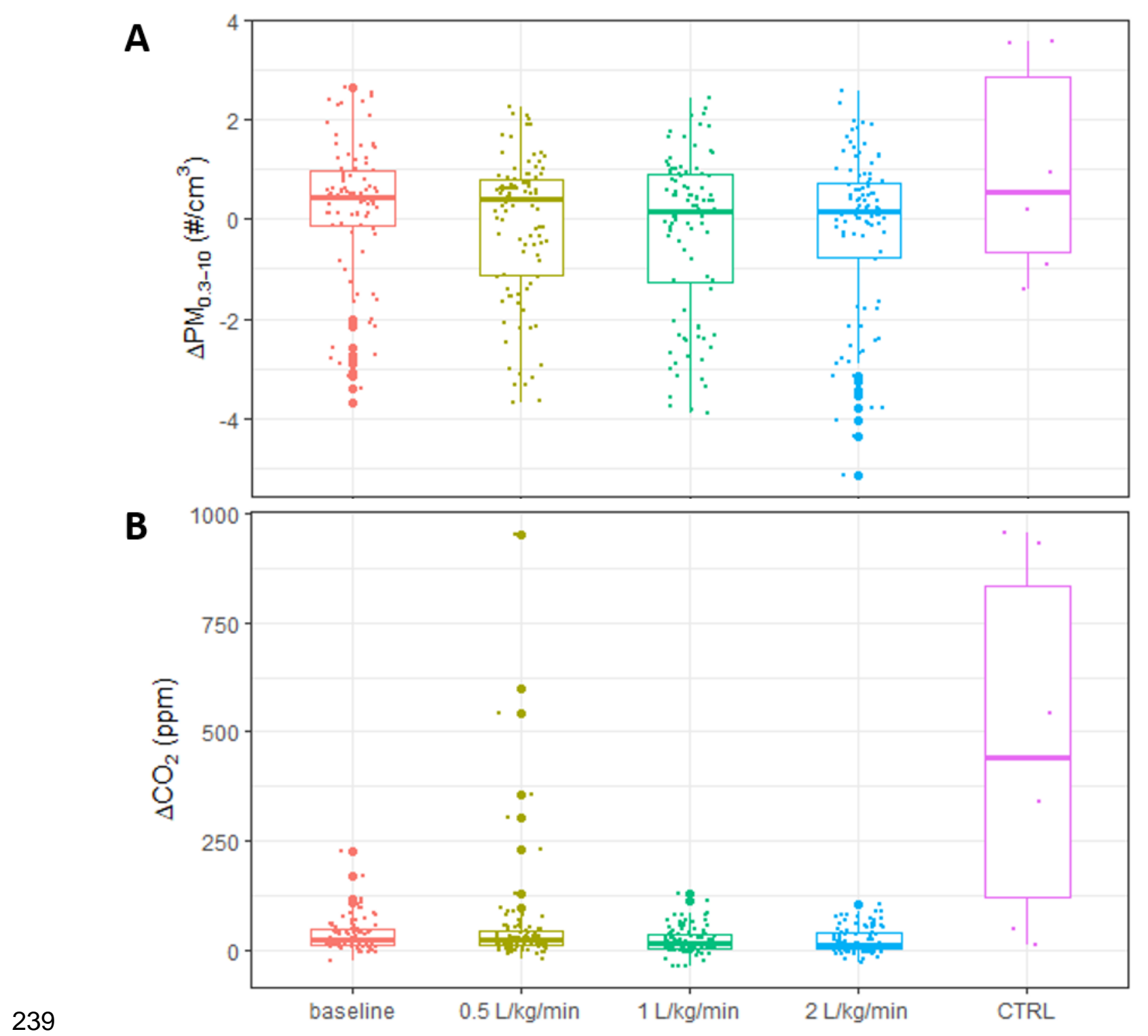


medRxiv preprint doi: https://doi.org/10.1101/2020.12.10.20245662; this version posted December 14, 2020. The copyright holder for this preprint (which was not certified by peer review) is the author/funder, who has granted medRxiv a license to display the preprint in perpetuity. It is made available under a CC-BY-NC-ND 4.0 International license .

$242 \Delta \mathrm{CO}_{2}$ is consistently positive. This implies that near-field measurements generally occurred in

243 the exhalations of the patient. Again, no relationship is observed with HFNC flow. The volitional

244 cough positive control resulted in substantially higher $\Delta \mathrm{CO}_{2}$.

245 While median $\Delta \mathrm{PM}_{0.3-10}$ and $\Delta \mathrm{CO}_{2}$ are consistently positive, there existed across-subject

246 variability in $\Delta \mathrm{PM}_{0.3-10}$ and $\Delta \mathrm{CO}_{2}$. For example, Patients $01,05,07$, and 09 had consistently

247 positive $\Delta \mathrm{PM}_{0.3-10}$ while Patients 04 and 06 were consistently negative (Figure 4a). Values of

$248 \Delta \mathrm{CO}_{2}$ were more consistently positive than $\Delta \mathrm{PM}_{0.3-10}$, as shown in Figure $4 \mathrm{~b}$, though again, there

249 exists variability across subjects.

250

251

252

253

254

255

256

257

258

259

260 
medRxiv preprint doi: https://doi.org/10.1101/2020.12.10.20245662; this version posted December 14, 2020. The copyright holder for this preprint (which was not certified by peer review) is the author/funder, who has granted medRxiv a license to display the preprint in perpetuity.

It is made available under a CC-BY-NC-ND 4.0 International license .

263 Figure 4. Panel A) Across-subjects variability in $\Delta \mathrm{PM}_{0.3-10}$ and Panel B) $\Delta \mathrm{CO}_{2}$. Each bar is the

264 median across 1-min averaged measurements at each HFNC flow condition for the indicated

265 subject. The error bars show the range across the 1-min averaged measurements (max-min). The

266 upper error bar for P01 at $0.5 \mathrm{~L} / \mathrm{kg} / \mathrm{min}$ extends to $310 \mathrm{ppm}$, not shown for figure clarity.

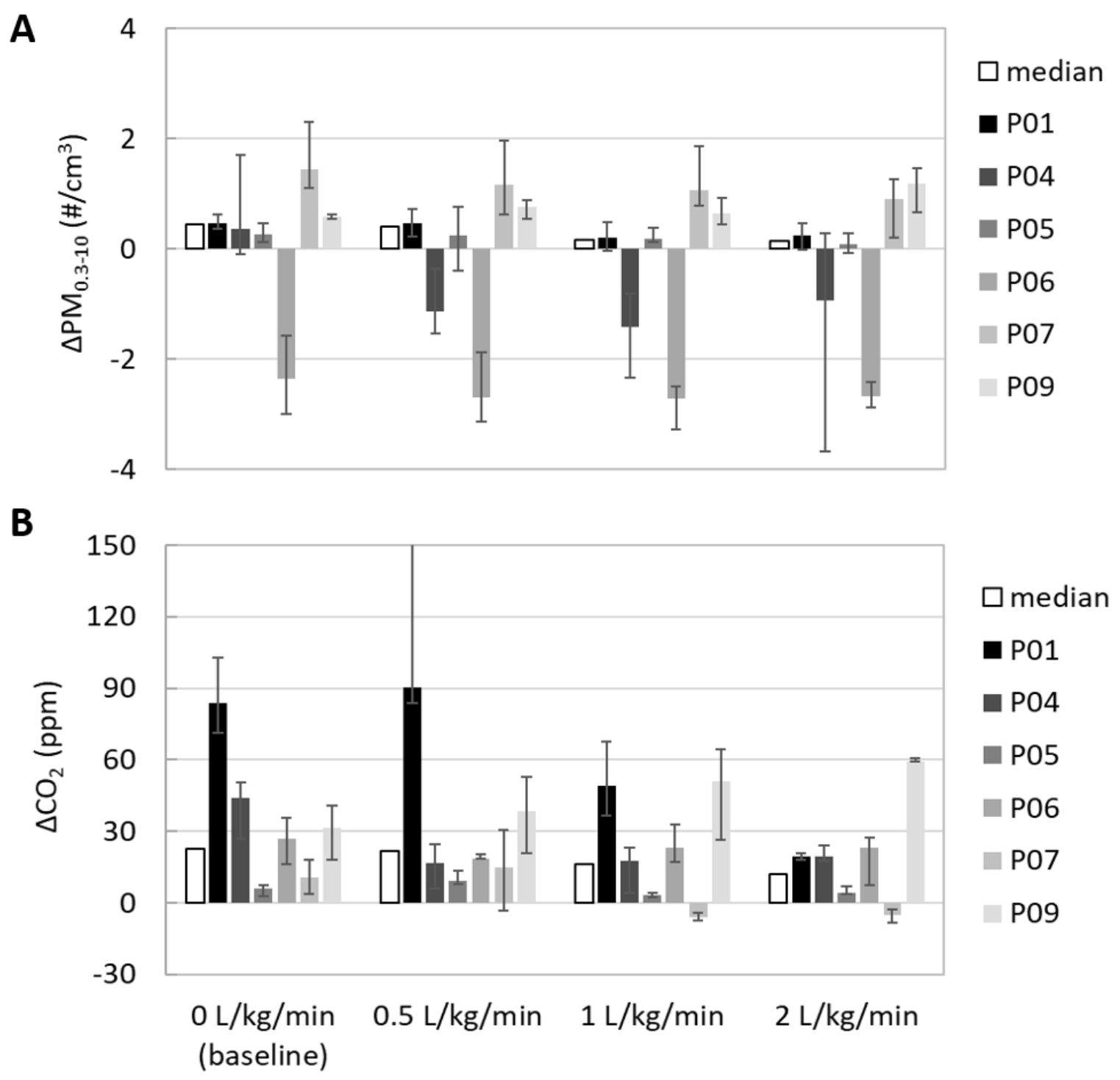

High flow nasal cannula flow condition

In Figure 5, we show the results of $\Delta \mathrm{PM}_{0.3-10}$ and $\Delta \mathrm{CO}_{2}$ for the two patients recruited who

269 had respiratory illness; results are limited to only one flowrate as we did not alter the patients' 
medRxiv preprint doi: https://doi.org/10.1101/2020.12.10.20245662; this version posted December 14, 2020. The copyright holder for this preprint (which was not certified by peer review) is the author/funder, who has granted medRxiv a license to display the preprint in perpetuity.

It is made available under a CC-BY-NC-ND 4.0 International license .

270 care directives. Since background measurements were infeasible, correction factors were used

271 from healthy patient studies conducted on the same respective days. As in healthy patients, we

272 observe variability in median $\Delta \mathrm{PM}_{0.3-10}$, with $\mathrm{P} 08$ negative and $\mathrm{P} 10$ positive. In contrast, $\Delta \mathrm{CO}_{2}$

273 for both patients is greater than zero, implying measurements occurred in patient breathing

274 planes.

275 Figure 5. Size resolved $\Delta \mathrm{PM}_{0.3-10}$ and $\Delta \mathrm{CO}_{2}$ for two patients with diagnosed respiratory illness.

276 Patient 08 was 3 months old and HFNC flowrate of 3 LPM, Patient 10 was 24 months with

277 HFNC flowrate of 15 LPM. Bars show median values of 1-min averaged measurements while

278 error bars show the range across a 10-min monitoring period.
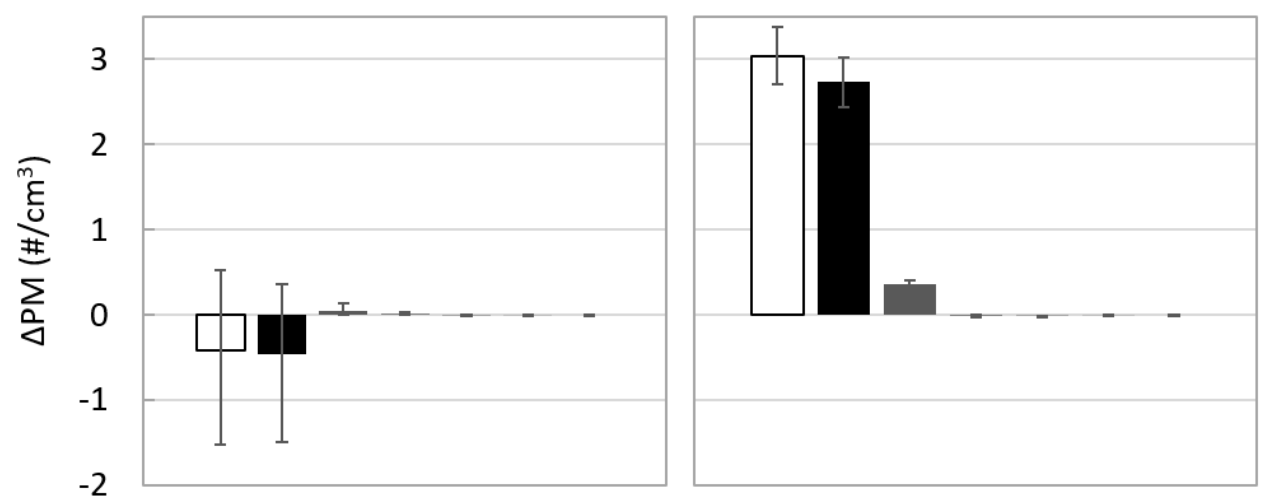

$\square \triangle \mathrm{PM}(0.3-10)$

$\triangle \mathrm{PM}(0.3-0.5)$

$\triangle \mathrm{PM}(0.5-1)$

$\triangle \mathrm{PM}(1-2.5)$

$\triangle \mathrm{PM}(2.5-5)$

$\triangle P M(5-10)$

$\Delta \mathrm{PM}(>10)$
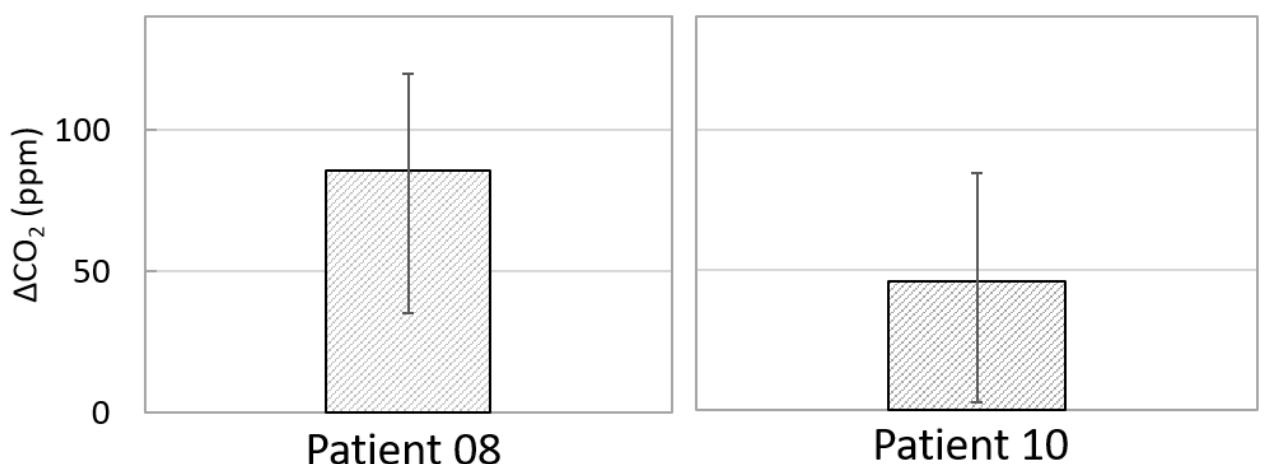

$\square \triangle \mathrm{CO} 2$ 
medRxiv preprint doi: https://doi.org/10.1101/2020.12.10.20245662; this version posted December $14,2020$. The copyright holder for this preprint (which was not certified by peer review) is the author/funder, who has granted medRxiv a license to display the preprint in perpetuity.

It is made available under a CC-BY-NC-ND 4.0 International license .

\section{Discussion:}

Results of this study indicate, across patients, that HFNC is not a substantial source of aerosol generation in the near-field beyond that of the patient's presence. Human breath contains particles; while results are variable across time for each patient and across patients, the median $\Delta \mathrm{PM}_{0.3-10}$ reported in this measurement is roughly consistent with the previous measurements of particle number concentrations on human breath. Johnson et al. ${ }^{9}$ report particle levels in speaking and coughing emissions in the size range of $0.5-1000 \mu \mathrm{m}$ of $0.16 \# / \mathrm{cm}^{3}$ and $0.22 \# / \mathrm{cm}^{3}$,

respectively. In this study, the complex fluid mechanics occurring in the patient's breathing plane due to exhaled breath, HFNC airflow, and the room airflows complicate further theoretical calculations of particle concentrations or emission rate originating from the patient. Humans also generate particles from activity, ${ }^{10}$ particles originating from the respiratory system versus, e.g., patient movement, cannot be differentiated here.

Median values of $\Delta \mathrm{PM}_{0.3-10}$ decreased slightly, though not statistically significantly, with increasing HFNC flow rate. We speculate this may be the result of enhanced mixing between forced air from subject and room air with higher velocities at higher HFNC flow conditions. We evaluate statistical significance of differences in medians of $\Delta \mathrm{PM}_{0.3-10}$ and $\Delta \mathrm{CO}_{2}$ across $\mathrm{HFNC}$ flow rates using a Wilcoxon rank sum test for $\Delta \mathrm{PM}_{0.3-10}$ and a student t-test for $\Delta \mathrm{CO}_{2}$, based on a Kolmogorv-Smirnov test for normality. Tests for normality and statistical testing employed the average of each HFNC condition conducted in duplicate across the six subjects (i.e., 12 independent samples of $\Delta \mathrm{PM}_{0.3-10}$ and $\Delta \mathrm{CO}_{2}$ for each condition). There are no statistically significant differences across $\Delta \mathrm{PM}_{0.3-10}$ or $\Delta \mathrm{CO}_{2}$ for any comparison of flow conditions. We set the threshold of significance as $p<0.0083$ for $95 \%$ confidence with Bonferonni correction for 
multiple comparisons. Calculated $p$-values are shown in the Table S1 of the Supporting

306 Information.

Results shown in Figure 4 reveal high variability in near-patient concentrations of PM and $\mathrm{CO}_{2}$. The explanation for the mechanism behind these observations is beyond the scope of this paper, though we speculate it is possible that patients with negative $\Delta \mathrm{PM}_{0.3-10}$ may be low emitters of particles or positioned in the space such that enhanced particle deposition is occurring in the turbulence generated from airflows interacting with the patient and associated equipment (bedding, instruments, etc.). Particles also deposit in the respiratory system. ${ }^{11}$ Patient 06 and Patient 04 measurements were conducted during relatively high room background PM levels, perhaps contributing to the negative $\Delta \mathrm{PM}_{0.3-10}$ observed. We note that prior studies have observed large variability in particle emission rate and concentrations in exhalations of humans during breathing and speaking. ${ }^{12-16}$ There is debate on the size of particles that are considered infectious, with droplet nuclei playing a larger role than previously considered ${ }^{17}$ - our study measured a broad range of potentially infectious particles including droplet nuclei.

Differences in near-field to far-field $\mathrm{CO}_{2}$ were larger and more pronounced than for PM. $\mathrm{CO}_{2}$ levels in human breath are $\sim 100 \mathrm{x}$ higher than ambient levels $(\sim 38,000$ vs. $400 \mathrm{ppm}) .{ }^{18} \mathrm{In}$ contrast, particle concentrations in human breath in the size range $0.3-10$ um are expected to be similar or lower than background levels measured in the patient rooms, e.g., Fairchild and Stampfer ${ }^{12}$ report particles in exhaled breath of $<0.1$ to $4 \# / \mathrm{cm}^{3}$. Notably, there is wide variation in particle concentrations in human breath and particle generation rates during coughing, with the presence of a respiratory infection and causing increased particle generation rate. ${ }^{19}$

In contrast to the variability in $\Delta \mathrm{PM}_{0.3-10}$ shown, $\Delta \mathrm{CO}_{2}$ is variable but more consistently positive (Figure 4b), implying that measurements were generally made in the breathing planes of 
medRxiv preprint doi: https://doi.org/10.1101/2020.12.10.20245662; this version posted December $14,2020$. The copyright holder for this preprint (which was not certified by peer review) is the author/funder, who has granted medRxiv a license to display the preprint in perpetuity.

It is made available under a CC-BY-NC-ND 4.0 International license .

328

329

330

331

332

333

334

335

336

337

338

339

340

341

342

343

344

345

346

347

348

349

350

the patients. There does not appear to be a relationship between elevated $\Delta \mathrm{CO}_{2}$ and $\Delta \mathrm{PM}_{0.3-10}$,

that is, high values of $\Delta \mathrm{CO}_{2}$ do not necessarily associate with high $\Delta \mathrm{PM}_{0.3-10}$. For example, $\mathrm{P} 01$

had the highest $\Delta \mathrm{CO}_{2}$ for three of four HFNC flow conditions, but $\Delta \mathrm{PM}_{0.3-10}$ was consistently

near the median value reported. Again, we speculate that this is a result of differences in particle

generation across subjects that are not related to metabolism (e.g., unknown physiological factors

that have been previously suggested as explaining "superemission" of aerosol during speech ${ }^{13}$ ).

Our limited sample of two patients with respiratory illness shown in Figure 5

demonstrates variability in near-field elevations of particles, with Patient 10 showing greater

$\Delta \mathrm{PM}_{0.3-10}$ than all healthy patients by a substantial margin. This appears largely driven by a

difference in the behavior of particles $0.3-0.5 \mu \mathrm{m}$, as the smallest size bin measured this size

range dominates the particle number concentration. For both patients with respiratory infection

we note there was an elevation in $\Delta \mathrm{PM}_{0.5-1}$, a size range that a prior study shows is statistically

significantly elevated during a respiratory infection. ${ }^{20}$ However, we did not have the ability to

vary HFNC flowrate, and so lack a baseline period of no HFNC flow for comparison.

\section{Conclusions:}

Our measurements indicate near-field $(\sim 0.5 \mathrm{~m})$ breathing plane concentrations of aerosol

and carbon dioxide are elevated by the presence of the patient with no HFNC flow, relative to the room far-field, by $0.45 \# / \mathrm{cm}^{3}$ and $23 \mathrm{ppm}$, for $\mathrm{PM}$ and $\mathrm{CO}_{2}$, respectively. Addition of $\mathrm{HFNC}$

flow in the range of $0.5-2 \mathrm{~L} / \mathrm{kg} / \mathrm{min}$ does not statistically significantly change the magnitude of near-field $\mathrm{PM}$ or $\mathrm{CO}_{2}$, corrected for the room far-field. These findings indicate that HFNC use in children may not substantially elevate clinician aerosol exposures greater than the presence of the patient alone, though we observe variability across patients. However, we caution that most of our empirical data were collected for healthy patients - our limited data for HFNC in children 
medRxiv preprint doi: https://doi.org/10.1101/2020.12.10.20245662; this version posted December 14, 2020. The copyright holder for this preprint (which was not certified by peer review) is the author/funder, who has granted medRxiv a license to display the preprint in perpetuity. It is made available under a CC-BY-NC-ND 4.0 International license.

351 with respiratory illness showed one patient with substantially elevated near-field $\Delta \mathrm{PM}_{0.3-10}$ while

352 for another patient we observe a small decrease in this metric. Further study of the impacts of

353 HFNC on particle generation and dispersion in patients with respiratory illness is warranted. 
medRxiv preprint doi: https://doi.org/10.1101/2020.12.10.20245662; this version posted December $14,2020$. The copyright holder for this preprint (which was not certified by peer review) is the author/funder, who has granted medRxiv a license to display the preprint in perpetuity.

It is made available under a CC-BY-NC-ND 4.0 International license .

354

355

356

357

358

359

360

361

362

363

364

365

366

367

368

369

370

371

372

373

374

375

376

377

378

379

380

381

382

383

384

385

386

387

388

389

390

\section{References:}

1. WHO. Clinical Management of Severe Acute Respiratory Infection When Novel Coronavirus (2019-NCoV) Infection Is Suspected. World Healthy Organization; 2020. Accessed December 5, 2020. https://www.who.int/publications-detail-redirect/clinicalmanagement-of-covid-19

2. Wu Q, Xing Y, Shi L, et al. Coinfection and Other Clinical Characteristics of COVID-19 in Children. Pediatrics. 2020;146(1). doi:10.1542/peds.2020-0961

3. Agarwal A, Basmaji J, Muttalib F, et al. High-flow nasal cannula for acute hypoxemic respiratory failure in patients with COVID-19: systematic reviews of effectiveness and its risks of aerosolization, dispersion, and infection transmission. Can J Anaesth. Published online June 15, 2020:1-32. doi:10.1007/s12630-020-01740-2

4. Kotoda M, Hishiyama S, Mitsui K, et al. Assessment of the potential for pathogen dispersal during high-flow nasal therapy. J Hosp Infect. 2020;104(4):534-537. doi:10.1016/j.jhin.2019.11.010

5. Loh N-HW, Tan Y, Taculod J, et al. The impact of high-flow nasal cannula (HFNC) on coughing distance: implications on its use during the novel coronavirus disease outbreak. Can J Anaesth. 2020;67(7):893-894. doi:10.1007/s12630-020-01634-3

6. Hui DS, Chow BK, Lo T, et al. Exhaled air dispersion during high-flow nasal cannula therapy versus CPAP via different masks. Eur Respir J. 2019;53(4). doi:10.1183/13993003.02339-2018

7. Elshof J, Hebbink RHJ, Duiverman ML, Hagmeijer R. High-flow nasal cannula for COVID19 patients: risk of bio-aerosol dispersion. Eur Respir J. 2020;56(4). doi:10.1183/13993003.03004-2020

8. O'Neil CA, Li J, Leavey A, et al. Characterization of Aerosols Generated During Patient Care Activities. Clin Infect Dis. 2017;65(8):1335-1341. doi:10.1093/cid/cix535

9. Johnson GR, Morawska L, Ristovski ZD, et al. Modality of human expired aerosol size distributions. Journal of Aerosol Science. 2011;42(12):839-851. doi:10.1016/j.jaerosci.2011.07.009

10. Ferro AR, Kopperud RJ, Hildemann LM. Source strengths for indoor human activities that resuspend particulate matter. Environ Sci Technol. 2004;38(6):1759-1764. doi:10.1021/es0263893

11. Hinds WC. Aerosol Technology: Properties, Behavior, and Measurement of Airborne Particles. 2 edition. Wiley-Interscience; 1999.

12. FAIRCHILD CI, STAMPFER JF. Particle Concentration in Exhaled Breath. American Industrial Hygiene Association Journal. 1987;48(11):948-949. doi:10.1080/15298668791385868 
medRxiv preprint doi: https://doi.org/10.1101/2020.12.10.20245662; this version posted December 14, 2020. The copyright holder for this preprint (which was not certified by peer review) is the author/funder, who has granted medRxiv a license to display the preprint in perpetuity.

It is made available under a CC-BY-NC-ND 4.0 International license .

391

392

393

394

395

396

397

398

399

400

401

402

403

404

405

406

407

408

409

410

411
13. Asadi S, Wexler AS, Cappa CD, Barreda S, Bouvier NM, Ristenpart WD. Aerosol emission and superemission during human speech increase with voice loudness. Scientific Reports. 2019;9(1):2348. doi:10.1038/s41598-019-38808-z

14. Edwards DA, Man JC, Brand P, et al. Inhaling to mitigate exhaled bioaerosols. PNAS. 2004;101(50):17383-17388. doi:10.1073/pnas.0408159101

15. Papineni RS, Rosenthal FS. The Size Distribution of Droplets in the Exhaled Breath of Healthy Human Subjects. Journal of Aerosol Medicine. 1997;10(2):105-116. doi:10.1089/jam.1997.10.105

16. Fabian P, McDevitt JJ, DeHaan WH, et al. Influenza Virus in Human Exhaled Breath: An Observational Study. PLOS ONE. 2008;3(7):e2691. doi:10.1371/journal.pone.0002691

17. Fennelly KP. Particle sizes of infectious aerosols: implications for infection control. The Lancet Respiratory Medicine. 2020;8(9):914-924. doi:10.1016/S2213-2600(20)30323-4

18. Rudnick SN, Milton DK. Risk of indoor airborne infection transmission estimated from carbon dioxide concentration. Indoor Air. 2003;13(3):237-245.

19. Lindsley WG, Pearce TA, Hudnall JB, et al. Quantity and Size Distribution of CoughGenerated Aerosol Particles Produced by Influenza Patients During and After Illness. J Occup Environ Hyg. 2012;9(7):443-449. doi:10.1080/15459624.2012.684582

20. Lee J, Yoo D, Ryu S, et al. Quantity, Size Distribution, and Characteristics of Coughgenerated Aerosol Produced by Patients with an Upper Respiratory Tract Infection. Aerosol Air Qual Res. 2019;19(4):840-853. doi:10.4209/aaqr.2018.01.0031 